\title{
Achieving the Effectiveness of Regional Development in the Context of Modern social- and-economic Reality
}

\author{
Irina Novikova*,Lydia Kovalenko, and Andrey Kulik \\ Kuban State Agrarian University named after I.T. Trubilin, Krasnodar, Russian Federation
}

\begin{abstract}
The social-and-economic transformations performed at the present stage of state development necessitate the formation and effective development of methods, mechanisms and tools for regional development. A key role in this development is occupied by an orientation towards the priorities of the implemented state social-and-economic policy. Based on the application of the method of relative differences, an order of ranking regions pursuant to the criterion of the current and strategic efficiency of the development of territories is proposed. The formation of a system of indicators that makes it possible to most correctly consider the largest number of factors characterizing the state of the regional economy will make it possible to maximize the potential of the territories, create conditions for achieving a socially oriented nature of transformations of the economic system while maintaining the stability of economic growth, and a gradual increase in the volume of national wealth. Assessing regional development based on the method of studying the competitive potential of territories seems to be effective, since it implies the possibility of improving the efficiency of managerial influence in this direction
\end{abstract}

\section{Introduction}

The implementation of regional development today is associated with a number of structural problems that reduce the potential efficiency of such development due to reasons of both economic management and organizational, as well as regulatory and legal nature. Management practice shows that the implementation of strategic planning [3] in the context of regional development is currently not performed systematically enough. In view of this, the tools of strategic planning implemented in the management of the social-and-economic development of the region's territory cannot be sufficiently effective [5].

From the point of view of management activities [4], performed by the state as the largest institution of social management, regional development may be characterized as the functioning of the meso-level, which assumes assistance to the social-and-economic dynamics of territorial structures - regions. As a rule, in this context, it is advisable to differentiate objects (by industry) in relation to which the managerial influence is performed: a branch of the economy, the social sphere, environmental development, etc.

\footnotetext{
*Corresponding author: ira_novikowa@mail.ru
} 


\section{Research methodology}

The peculiarities of the regulation of regional development as the most important direction of the implementation of managerial influence [2] in relation to territorial systems are presented in the works of M.V. Kivarina [10], P.N. Mulloev [12] et al. The research of the search for effective methods, tools and mechanisms of regional development is the subject of research by K.A. Goncharova [9]. It should be noted that the evolution of ideas about the managerial, organizational and regulatory framework of regional development in the scientific works of modern researchers is considered in the context of its economic and social significance. However, at present there is no consensus on the model [6] of the most effective implementation of regional development, as well as on the system of factors influencing the competitive advantages of regions [8] in the context of their development and the key disadvantages of this type of regulatory activity [7].

The main source for writing this article was familiarization with the experience of regional development in the Russian Federation constituent entities, including the Krasnodar Territory. The article is based on the use of methods of theoretical research, system analysis, allowing to consider processes and phenomena in their relationship.

\section{Research results}

The implementation of regional development is a multi-entity activity, since it is formed as a result of the functioning of several types of organizations (Fig. 1 shows the structure of the scale of activities of such organizations in the context of organizational and legal forms).

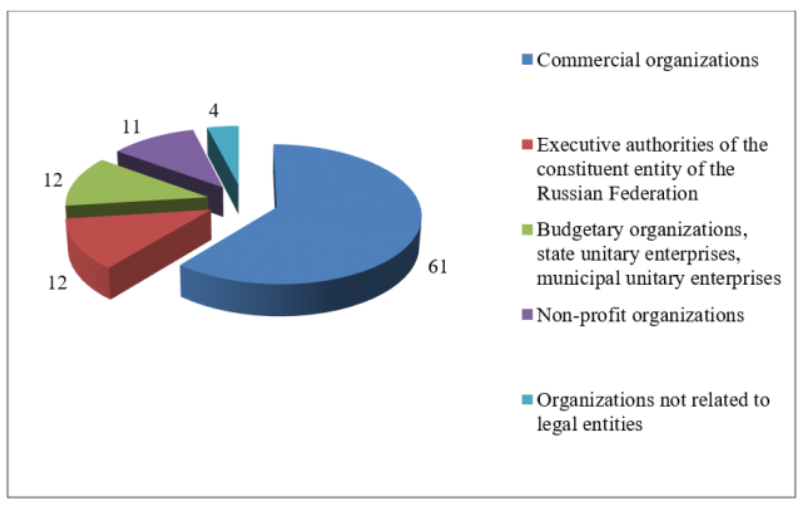

Fig. 1. The structure of organizations participating in the implementation of regional development, $\%$

Management practice shows that the most effective tool for implementing regional development is coefficient analysis (tab. 1).

Table 1. Analysis of the main coefficients of regional development of the Krasnodar Territory.

\begin{tabular}{|c|c|c|c|c|c|c|}
\hline Indicator & $\mathbf{2 0 1 6}$ & $\mathbf{2 0 1 7}$ & $\mathbf{2 0 1 8}$ & $\mathbf{2 0 1 9}$ & $\mathbf{2 0 2 0}$ & $\begin{array}{c}\text { Absolute } \\
\text { deviation } \\
\mathbf{2 0 2 0} \text { to } \\
\mathbf{2 0 1 6}\end{array}$ \\
\hline $\begin{array}{c}\text { Employment rate of the } \\
\text { population, \% }\end{array}$ & 26.4 & 26.2 & 26.5 & 26.6 & 26.1 & -0.3 \\
\hline $\begin{array}{c}\text { Coefficient of provision of } \\
\text { the population with retail } \\
\text { space of a modern format } \\
\text { m }^{2} / 1000 \text { people }\end{array}$ & 164.5 & 162.7 & 161.0 & 158.7 & 155.4 & -9.1 \\
\hline
\end{tabular}




\begin{tabular}{|c|c|c|c|c|c|c|}
\hline $\begin{array}{c}\text { Coefficient of provision of } \\
\text { the population with } \\
\text { commodity stocks, RUR } \\
\text { th/person }\end{array}$ & 8.2 & 8.3 & 9.2 & 9.3 & 9.4 & +1.2 \\
\hline $\begin{array}{c}\text { Coefficient of budgetary } \\
\text { provision of the population, } \\
\text { RUR th/person }\end{array}$ & 18.8 & 19.1 & 20.6 & 21.4 & 21.6 & +2.8 \\
\hline $\begin{array}{c}\text { Territory budget } \\
\text { performance coefficient, } \\
\text { RUR th/ha }\end{array}$ & 18.2 & 19.6 & 18.0 & 17.2 & 17.0 & -1.2 \\
\hline $\begin{array}{c}\text { Investment level per capita, } \\
\text { RUR th/person }\end{array}$ & 30.5 & 15.13 & 12.4 & 8.7 & 8.9 & -21.6 \\
\hline $\begin{array}{c}\text { Infrastructure provision } \\
\text { ratio of the population, } \\
\text { RUR th/person }\end{array}$ & 20.8 & 18.4 & 17.9 & 17.6 & 17.3 & -3.5 \\
\hline $\begin{array}{c}\text { Import substitution } \\
\text { coefficient, \% }\end{array}$ & 50.3 & 54.5 & 54.4 & 54.0 & 53.2 & +2.9 \\
\hline
\end{tabular}

After analyzing the coefficient analysis of the efficiency of regional development in the Krasnodar Territory, we came to the conclusion that many coefficients indicate the presence of negative dynamics in this direction. Thus, a decrease in the employment rate of the population indicates an increase in unemployment and an increase in tension in the regional labor market in the Krasnodar Territory. It is natural that this process is largely a consequence of the pandemic, however, one cannot exclude the presence of crisis phenomena in the economy (first of all, we are talking about a decrease in the efficiency of functioning of small and medium-sized businesses, which leads to a decrease in the number of jobs).

The provision of the population with modern retail space affects not only the economic, but also the social efficiency of regional development. The population of the Krasnodar Territory is increasing from year to year, and this process is significantly ahead of the construction of modern-format squares, which causes a decrease in the value of this indicator of regional development.

The analysis of the dynamics of regional development coefficients made it possible to state a significant decrease in investment per capita, which is explained not only by an increase in the number of residents of the Krasnodar Territory, but also by the presence of economic problems that reduce the investment attractiveness of the region in the long term.

The indicator of infrastructural provision of the population of the Krasnodar Territory during the study period also tends to decrease. Practice shows that such a negative dynamics of this indicator is due to the deterioration of the communal and engineering infrastructures of the region, as well as a decrease in the efficiency of functioning of social infrastructure facilities and a decrease in their number.

To obtain a comprehensive understanding of the efficiency of the regional development of the Krasnodar Territory [13], it is advisable to compare the main coefficients of such development with the Rostov region and the Russian Federation as a whole (tab. 2).

Table 2. Analysis of the main coefficients of regional development of the Krasnodar region in comparison with the Rostov region and the Russian Federation

\begin{tabular}{|c|c|c|c|c|c|c|}
\hline \multirow{2}{*}{ Indicator } & \multicolumn{3}{|c|}{$\mathbf{2 0 1 9}$} & \multicolumn{3}{|c|}{$\mathbf{2 0 2 0}$} \\
\cline { 2 - 7 } & $\begin{array}{c}\text { Krasnoda } \\
\mathbf{r} \\
\text { Territory }\end{array}$ & $\begin{array}{c}\text { Rostov } \\
\text { region }\end{array}$ & RF & $\begin{array}{c}\text { Krasno } \\
\text { dar } \\
\text { Territo } \\
\text { ry }\end{array}$ & $\begin{array}{c}\text { Rosto } \\
\mathbf{v} \\
\text { region }\end{array}$ & RF \\
\hline $\begin{array}{c}\text { Employment rate of the } \\
\text { population, \% }\end{array}$ & 26.6 & 26.9 & 24.5 & 26.1 & 27.4 & 25.3 \\
\hline
\end{tabular}




\begin{tabular}{|c|c|c|c|c|c|c|}
\hline $\begin{array}{c}\text { Coefficient of provision } \\
\text { of the population with } \\
\text { retail space of a modern } \\
\text { format m2/1,000 people }\end{array}$ & 158.7 & 166.9 & 170.1 & 155.4 & 166.2 & 158.6 \\
\hline $\begin{array}{c}\text { Coefficient of provision } \\
\text { of the population with } \\
\text { commodity stocks, RUR } \\
\text { th/person }\end{array}$ & 9.3 & 7.8 & 8.1 & 9.4 & 8.6 & 8.9 \\
\hline $\begin{array}{c}\text { Coefficient of budgetary } \\
\text { provision of the } \\
\text { population, RUR } \\
\text { th/person }\end{array}$ & 21.4 & 21.6 & 19.1 & 21.6 & 22.5 & 18.7 \\
\hline $\begin{array}{c}\text { Territory budget } \\
\text { performance coefficient, } \\
\text { RUR th/ha }\end{array}$ & 17.2 & 18.8 & 18.0 & 17.0 & 19.1 & 16.6 \\
\hline $\begin{array}{c}\text { Investment level per } \\
\text { capita, RUR th/person }\end{array}$ & 8.7 & 13.6 & 13.0 & 8.9 & 14.0 & 11.7 \\
\hline $\begin{array}{c}\text { Infrastructure provision } \\
\text { ratio of the population, } \\
\text { RUR th/person }\end{array}$ & 17.6 & 19.0 & 18.2 & 17.3 & 18.9 & 17.2 \\
\hline $\begin{array}{c}\text { Import substitution } \\
\text { coefficient, \% }\end{array}$ & 54.0 & 54.9 & 50.9 & 53.2 & 55.8 & 50.1 \\
\hline
\end{tabular}

The comparative analysis shows that the Krasnodar Territory is inferior in the efficiency of regional development in terms of indicators such as the provision of the population with modern retail space, the budgetary performance of the territories, as well as the infrastructure provision of the population.

Fig. 2 reflects the delineation of the Russian Federation regions pursuant to the criterion of comfort for living. The analysis showed that the Krasnodar Territory is inferior to the Rostov Region in the context of the estimated indicator. Herewith, the Astrakhan and Volgograd regions, in the opinion of the residents of the constituent entities of the country, are recognized as less comfortable for life than the Rostov Region and Krasnodar Territory.

The distribution of regions pursuant to the level of comfort for living is a very multidimensional process.

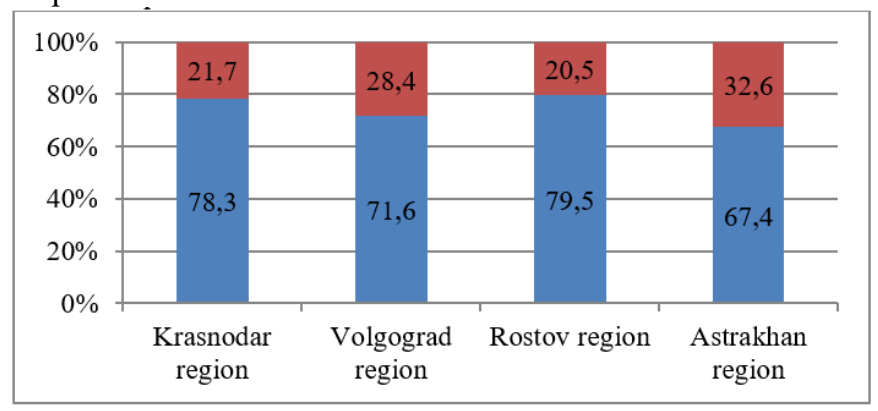

Fig. 2. Assessment of the comfort of the regions for living pursuant to All-Russian Center for the Study of Public Opinion, \%

Pursuant to some experts, the formation of this process is largely influenced by secondary non-economic factors, such as the image of the region, ethnocultural features of the regional system, the prestige of the territory, etc.

In view of the multifactorial nature of the assessment of regional development, the authors consider it advisable to use such a tool for assessing the efficiency of this type of development as an analysis of competitive potential. 
Table 3. Calculation of the regional development efficiency index in 2020

\begin{tabular}{|c|c|c|c|c|}
\hline Indicator & $\begin{array}{c}\text { Krasnod } \\
\text { ar } \\
\text { Territory }\end{array}$ & $\begin{array}{l}\text { Volgograd } \\
\text { region }\end{array}$ & $\begin{array}{l}\text { Rostov } \\
\text { region }\end{array}$ & $\begin{array}{c}\text { Astrakh } \\
\text { an } \\
\text { region }\end{array}$ \\
\hline \multicolumn{5}{|c|}{ Private indicators of the index of strategic efficiency } \\
\hline $\begin{array}{l}\text { Fixed capital investments per } \\
\text { capita, RUR. }\end{array}$ & $94,562.9$ & $69,129.8$ & $58,841.6$ & $98,147.4$ \\
\hline $\begin{array}{l}\text { Research and development } \\
\text { organizations, units }\end{array}$ & 106 & 53 & 100 & 25 \\
\hline $\begin{array}{c}\text { The number of personnel engaged } \\
\text { in research and development, } \\
\text { people }\end{array}$ & 9,265 & 3,958 & 12,556 & 933 \\
\hline $\begin{array}{c}\text { Internal costs for research and } \\
\text { development, RUR mln }\end{array}$ & $6,792.0$ & $3,417.7$ & $13,682.2$ & 563.1 \\
\hline $\begin{array}{l}\text { Foreign investment in fixed assets } \\
\text { per capita, USD }\end{array}$ & 191.3 & 143.6 & 476.4 & 43.2 \\
\hline \multicolumn{5}{|l|}{$\begin{array}{c}\text { Strategic development efficiency } \\
\text { index }\end{array}$} \\
\hline \multicolumn{5}{|c|}{ Private indicators of the index of current efficiency } \\
\hline GRP per capita, RUR th & $330,100.2$ & $278,961.2$ & $235,695.9$ & $\begin{array}{c}283,591 . \\
2\end{array}$ \\
\hline $\begin{array}{l}\text { Fixed assets in the economy per } \\
\text { capita, RUR th }\end{array}$ & 865.2 & 714.1 & 556.1 & $1,034.1$ \\
\hline $\begin{array}{c}\text { Share of unprofitable enterprises } \\
\text { and organizations, } \%\end{array}$ & 28.9 & 37.4 & 28.7 & 45.4 \\
\hline $\begin{array}{l}\text { Unemployment rate to the number } \\
\text { of economically active population, } \\
\%\end{array}$ & 6.0 & 7.2 & 6.1 & 7.5 \\
\hline \multicolumn{5}{|l|}{$\begin{array}{l}\text { Average per capita monetary } \\
\text { income of the population per } \\
\text { month, RUR. }\end{array}$} \\
\hline $\begin{array}{l}\text { The number of registered } \\
\text { corruption-related crimes (Article } \\
\text { 290, } 285 \text { of the Criminal Code) }\end{array}$ & 0 & 0.608 & 0.475 & 1 \\
\hline $\begin{array}{c}\text { Share of business entities in the } \\
\text { total number of surveyed business } \\
\text { entities who believe that the state } \\
\text { of the competitive environment } \\
\text { has enhanced over the past year, } \\
\%\end{array}$ & 0 & 0.938 & 1 & 0.753 \\
\hline Current efficiency index & 0.198 & 0.614 & 0.825 & 0.584 \\
\hline $\begin{array}{c}\text { Composite development } \\
\text { efficiency index }\end{array}$ & 0.677 & 0.389 & 0.688 & 0.274 \\
\hline RF subject rank & 2 & 3 & 1 & 4 \\
\hline
\end{tabular}

It is important to note that the assessment of regional development based on the method of studying the competitive potential of territories seems to be effective in the following cases:

- at certain time intervals;

- in a situation where the compared territorial entities are comparable in the main groups of characteristics.

Based on the analysis of a comprehensive assessment of regional development, the development of a management impact strategy is performed. Management practice shows 
that it is advisable to base such an impact on the indices of the current and strategic efficiency of regional development. Table 5 shows the ratio of the indicated indices in the context of groups of regions by the type of regional development is determined.

Table 4. Correlation of values of indices of current and strategic efficiency of development of target groups (structured by the authors).

\begin{tabular}{|c|c|c|}
\hline \multirow{2}{*}{ Region groups } & \multicolumn{2}{|c|}{ Values } \\
\cline { 2 - 3 } & $\begin{array}{c}\text { Index of current } \\
\text { development efficiency (Itr) }\end{array}$ & $\begin{array}{c}\text { Index of strategic } \\
\text { development efficiency } \\
\text { (Isr) }\end{array}$ \\
\hline Stopping development & $0 \leq \mathrm{I}_{\mathrm{tc}} \leq 0.5$ & $0 \leq \mathrm{U}_{\mathrm{sc}} \leq 0.5$ \\
\hline Inertial development & $0.5<\mathrm{I}_{\mathrm{tc}} \leq 1$ & $0 \leq \mathrm{I}_{\mathrm{sc}} \leq 0.5$ \\
\hline Stimulated development & $0 \leq \mathrm{I}_{\mathrm{tc}} \leq 0.5$ & $0.5<\mathrm{I}_{\mathrm{sc}} \leq 1$ \\
\hline Innovative development & $0.5<\mathrm{I}_{\mathrm{tc}} \leq 1$ & $0.5<\mathrm{I}_{\mathrm{sc}} \leq 1$ \\
\hline
\end{tabular}

The assignment of a region to one of the groups presented determines the type of managerial impact on the implementation of regional development in the long term.

Therefore, the regions of the stopping type require to:

- determine the reasons for the slowdown in social and economic development;

- identify the objectivity/subjectivity of such reasons;

- determine the possibility of adjusting the management impact for the complete or partial elimination of the reasons for the slowdown in social and economic development.

For regions of inertial development, managerial influence involves maintaining the stability of the dynamics of the economic system due to the stability of inertial processes in the social-and-economic sphere.

In regions of stimulated development, incentives for primary and secondary impact should be identified. When developing a strategy for management impact, considering incentives of primary influence is a priority.

For effective management of regions of innovative development, it is necessary to determine the general vector of such development, the role of innovations in the economy sectors and the social sphere. It is also necessary to consider the need to support innovative enterprises and organizations from the state.

\section{Discussion}

To determine the vector of the most effective direction of regional development, one of the most important areas of regulatory impact is the choice of a system of indicators that form the final value of such efficiency both in the medium and strategic perspective.

Since the statistics do not fully reflect the general welfare of the territory, since the development of the subjects is influenced by more criterial indicators of the state of the regional economy, in particular, the standard of living of the population is an indicator of the consequence of the level of development of the regional economy. Nevertheless, indirectly, more aggregated indicators may more fully indicate existing or emerging negative trends in the development of territories.

In addition to statistical and coefficient indicators, an essential parameter of the efficiency of regional development is the assessment of the comfort of living in the region. This indicator is cumulative and differs in a high proportion of subjectivity, however, in many respects it is of decisive importance in establishing the general level of competitiveness of the region.

From the point of view of modern prospects for regional development, special attention should be paid to such a multidimensional indicator as the import substitution coefficient, 
since it indicates the prospects for the formation of strategic regional competitiveness in the context of the sanctions regime [14].

\section{Conclusion}

The typology of regions pursuant to the criterion of the state of the current and strategic efficiency of development allows not only to form vectors of managerial impact in the long term, but also to correct the current state of regional governance.

The study of the existing methodological approaches to assessing the efficiency of the development of territories at the present stage showed that a unified, generally accepted methodology for conducting such an assessment has not been developed by modern science. Russian and foreign scientists are actively working in this direction.

Pursuant to the authors, it is possible to increase the efficiency of regional development if the following conditions are met:

1. Achievement of a relatively high standard of living of the region's population, which may be ensured as a result of the social orientation of the economic policy pursued in the region. The formation of territorial attractiveness, as the management practice shows, is also very important for determining the level of living comfort in the region.

2. Formation of conditions for achieving maximum efficiency of the functioning of the economic mechanism of the region. This mechanism includes such social-and-economic categories as the competitiveness of the region as a whole and its individual economic subsystems, innovative development, provision of the population with goods and services, implementation of the import substitution policy, etc.

3. Implementation of the strategy of investment attractiveness of the territory. Pursuant to the results of analytical studies, many regions at the present stage of their development are characterized by a decrease in investment attractiveness and capital outflow. Herewith, the use of tools of effective public administration, including the program-targeted method of management, makes it possible to increase the investment attractiveness of territories.

4. Assistance in the development of small and medium-sized businesses in the region, which largely forms the gross regional product. In addition, an important function of this industry is to provide the population of the regions with jobs. In order to support small and medium-sized businesses, it is advisable to use the activation of tax policy instruments and the implementation of information and consulting support for business.

5. Development of the resort and tourist complex, including its alternative subsectors, such as ethnic [11], gastronomic, agricultural [1], ecological types of tourist activities.

Mathematical modeling of scenarios for the development of territories allows to reduce the complexity of the joint assessment of regional systems in order to obtain the most relevant forecasts and make effective management decisions.

Thus, the formation of a system of indicators that makes it possible to most correctly consider the largest number of factors characterizing the state of the regional economy will make it possible to use the potential of the territories to the maximum extent, create conditions for achieving a socially-oriented nature of transformations of the economic system while maintaining the stability of economic growth, and a gradual increase in the volume of national wealth.

\section{References}

1. L.V. Kovalenko, A.A. Kulik, The role of agritourism in improving the management efficiency of integrated structures in the economy of the Krasnodar region. IOP 
conference series: earth and environmental science. International Conference. Stavropol, p. 12002 (2021)

2. W. Miller, Research-Technology Management 44(5), 26 (2001)

3. F. Nakakubo, Introduction to Alternative Investment Strategies (NLI Research Papers, October 2002, Tokyo)

4. L. Pritchett, Does Learning to Add Up Add Up? The Returns to Schooling in Aggregate Data (Kennedy School of Government, Harvard University, 2004)

5. Risk Management guidelines for derivatives. Basle, July 1994.189 Roland Kenett. Towards a grand unified theory of risk. Operational Risk, pp. 61-69 (London, Infroma Business Publishing, 2000)

6. D. Tennenhouse, Research-Technology Management 47(4), 19 (2004)

7. World Investment Report: 2004. The Shift Towards Services. UNCTAD. N. Y; Geneva, (2004)

8. V.M. Bezgin, I.I. Novikova, Bulletin of scientific and technical creativity of youth of the Kuban State Agrarian University in 4 parts, 208 (Krasnodar: FSBEI HPE "Kuban State Agrarian University", 2016)

9. K.A. Goncharova, Russian political process in the regional dimension: history, theory, practice 10, 24 (2017)

10. M.V. Kivarina, Beneficium 3 (32), 34 (2019)

11. E. N. Klochko, L.V. Kovalenko, Management Accounting 3, 33 (2020)

12. P.N. Mulloyev, Bulletin of the Academy of Sciences of the Republic of Tajikistan. Department of Social Sciences 1 (259), 117 (2020)

13. I.I. Novikova, L.V. Kovalenko, Economics and Entrepreneurship 5 (118), 339 (2020)

14. M.V. Rudeva, I.I. Novikova, Competitiveness in the context of globalization. International scientific-practical conference on topical issues of economics and the humanities in 2015: materials of the scientific-practical conference, 199 (Krasnodar: Krasnodar Center for Science and Technology, 2015) 